\title{
HONOUR AND SHAME IN PSALM 44
}

\author{
Leonard P Maré \\ School of Biblical Studies and Bible Languages \\ North-West University
}

\begin{abstract}
Honour and shame were core social values of the ancient Mediterranean world. Nearly everything pertaining to relationships was determined by these two concepts. Honour was the goal, passion and hope of everyone wishing to succeed in life. Being shamed was a social catastrophe. Honour was thus understood as the direct contrast of shame, specifically negative shame, because positive shame, usually ascribed to females, was understood to be a virtue. Honour and shame took a central place in relationships between humans, but also in the relationship between God and human. These concepts of honour and shame play a central role in Psalm 44. The first stanza with the joyful exuberance of Israel remembering and celebrating God's glorious deeds on their behalf, serves as an expression of Israel's honour, and the other nations' shame. In the lament of stanza 2 God is blamed for the people's suffering. God has rejected and humbled them; they are disgraced and shamed. God's rejection is experienced in various ways; the end result is that Israel is covered with disgrace and shame. In the third stanza the plea of innocence is an expression of their conviction that they don't deserve their position of shame, and that they should be restored to a position of honour. In stanza 4 the people petition God to act on their behalf again and thus change their shame into honour.
\end{abstract}

Key Words: Honour; Shame; Psalm 44; Covenant

\section{Introduction}

Honour and shame were core social values of the ancient Mediterranean world. Nearly everything pertaining to relationships, a person's identity and social status was determined by these two concepts. Honour was perceived to be the foundation of someone's reputation and position in society; and also indicative of the power and precedence one had in that society. Honour can therefore be described as one's claim to personal worth in one's own eyes and in the eyes of others (cf. Bergant 1994:33; Matthews \& Benjamin 1994:11; Simkins 1994:49). Honour therefore was the goal, passion and hope of everyone wishing to succeed in life. Being shamed was a social catastrophe. Honour was thus understood as the direct contrast of shame, specifically negative shame, because positive shame, usually ascribed to females, was understood to be a virtue. ${ }^{1}$

From a male perspective honour thus stood for someone's rightful position in society discernible by boundaries of power, sexual status and position on the social ladder. There are two types of honour: Ascribed honour refers to the honour with which one is born. It happens passively to someone through birth, ethnicity, family reputation, gender, wealth, or bequest by prominent persons of power. Acquired honour is actively sought and acquired

Shame, when attributed to men, is regarded as a negative, resulting in a state of dishonour and disrespect. However, when shame is attributed to women, it is regarded as a positive and serves as an indication of a woman's sexual modesty and social propriety (Brayford 1999:163-165). 
often at the expense of one's equals in the social contest of challenge and response. It could therefore be won and lost on a daily basis through acts of benefaction and the agonistic contest of challenge and riposte. Public encounters became the arena where honour was given and taken. A challenger conveys some sort of message in the public arena, and the public nature of the act assures the response of the receiving individual. ${ }^{2}$ The presupposition in an honour / shame culture was that all goods (including honour) were in limited supply. People would therefore protect their honour and fight to retrieve it if it has been lost. If honour was not in limited supply, losing some would carry no consequences. However, limited honour meant that extravagance on anyone's behalf created lack for someone else (cf. Crook 2009:593; DeSilva 2008:288; Hobbs 1997:502; Robbins 1996:76, 89-90).

\section{Honour and Shame in the Book of Psalms}

Evidence of the social value system of honour and shame in the Old Testament occurs often in the patriarchal narratives and the Deuteronomistic history (e g Gen 34; 1 Sam 31; 2 Sam 13). This has resulted in a number of scholarly treatments of these texts. ${ }^{3}$ The prophetic literature of the Hebrew Bible also attests to these concepts, in a powerful and often extremely shocking way. Metaphors referring to nakedness, sexuality and sexual promiscuity are often employed by the prophets in order to correct the behaviour of the recipients of their message. This corpus of literature has also received attention from scholars. ${ }^{4}$ The occurrence of these concepts in the Book of Psalms has, however, received little scholarly attention. This suggests a gap in our knowledge of the subject and begs more research to be done in this regard.

\footnotetext{
Cf. Robbins (1996:80-81) for a discussion of challenge-response as social communication.
}

3 Bechtel (1991:47-76); Matthews (1998:97-112); Stansell (1994:55-79); Stone (1995:87-107); cf. also Tucker (2007:466) for additional references.

4 Cf. Bartusch (2009:455-463); Botha (2001:392-403); Odell (1991:101-112); Simkins (1994:41-55); cf. also Tucker (2007:466-467) for additional references.

5 Cf. Botha (1998a:24-39); Botha (1998b:525-33); Botha (1999:389-400); Botha (2002:320-34). Tucker (2007:465-480) in his treatment of the subject, has focussed explicitly on the connection between shame (and honour) and patron-client relations in communal laments. Cottrill (2008) did an excellent study on honour and shame in individual laments. The goal of her research was to describe the identity created for the 'I' in the laments of the individual not as a historical figure, but as a rhetorical device $(2008: 1,9)$. In the third chapter of her book (58-99) Cottrill discussed the enemy, the 'hostile other' as an inhabitant of the figured world of the psalmist. There are two aspects to the relational narrative between the psalmist and the enemy. On the one hand, the relational narrative is one of endangerment and social vulnerability, where the psalmist is exposed before the enemy, while on the other hand the relational narrative is rooted in the psalmist's language of aggression and dominance, affording the psalmist a rhetorical position of power (58). Cottrill states that social identity in relation to the hostile other is articulated in a discourse of honour and shame (59). The worldview which determines the relation between the psalmist and the enemy; how the psalmist perceives and responds to the enemy, is one where honour and shame define and control social and personal worth. The language of honour and shame in the figured world of the psalms of lament recognizes that social respect and the acknowledgment of that respect is the measure of one's social value. Social relationshipsare thus structured as competitive and hierarchical, resulting in a perception of social restoration where the psalmist moves from a position of social inferiority to one of social superiority. When the psalmist is under attack and thus placed in a position of social inferiority he is shamed, but when Yahweh is rallied to act on behalf of the psalmist, he returns to a position of restored honour and thus social superiority. She further analysed the relationship between the psalmist and God in chapter four by using a patronage model (100-137). The patron-client (Godpsalmist) relationship comprises four features: it is personal, vertical, of mutual benefit, and voluntary. These facets are characterized by trust, hierarchical social standing amongst partners, loyalty and the possibility for social respect or disgrace (honour/shame) to come the way of either partner if a breach of mutual expectations should happen. 
"The book of Psalms is especially rich in the language and conceptual framework of honor and shame" (DeSilva 2008:288; the following overview of honour and shame in the Book of Psalms is summarized from DeSilva 2008:288-291). ${ }^{6}$ When the didactic function of many of the psalms is combined with their public recitation, these texts function as "epideictic oratory, celebrating honorable patterns of life and behavior, holding these esteemed patterns up before the collective community to be internalized" (288-289). Examples of these are Psalms $1 ; 15 ; 19: 7-11 ; 24: 3-5 ; 32: 1-2 ; 101 ; 112 ; 119: 1-8 ; 133$.

The psalms also attest to the individual's or nation's experience of being shamed and praying for a turnaround in their fortunes, and thus indicate indirectly that the avoidance of disgrace and preservation of honour are significant concerns of the people that created and read these texts (289).

The psalmists expected that righteous living would result in the enjoyment of honour and the other goods of life (cf. Pss. 34:5,8-9; 37:18-19; 127:5). They frequently prayed that they would not be put to shame by their enemies, often claiming that they were relying on God's help (cf. Pss. 25:2, 20; 31:17; 38:16). Those who trust God and fear Him should not experience disgrace; it is rather the fate of those who break faith with the covenant (cf. Ps. 25:3) and who worship idols (cf. Ps. 97:7; 289).

However, their experience repeatedly contradicted the expectations of their theology. The psalmists would regularly, despite their claim of innocence, encounter taunts from their enemies. Whether they confessed uprightness (Ps. 7:5) or prayed for forgiveness in order that they would not be shamed and scorned (Ps. 39:8), their commitment to continue in their obedience of the Torah and their belief that God will secure the honour of those who stay loyal to the covenant, remain the foundation for their prayer and confidence (Pss. 119:31,51,80;289).

The psalmists display this same confidence when they pray for a reversal of their fortunes, asking that shame and disgrace should befall their enemies (cf. Pss. 6:10; 35:4,26; $40: 14-15 ; 70: 2-3 ; 71: 13,24 ; 109: 29)$. These enemies are among those who do not keep the covenant; the psalmists therefore pray that their enemies be put in their right place below the righteous petitioner (Pss. 27:6; 71:21,24). The shaming of the enemies corresponds to the vindication of the righteous. However, they do not seek to shame their enemies personally; they commit their cause to God (289).

This happens at national level as well. The psalmists expected that Israel should be exalted above their enemies (Ps. 72:9-11) instead of being brought low before them (Ps. $89: 19,24,27)$. The nation, however, did experience humiliation from their enemies and they were subjected to disgrace (Pss. 79:4; 89:41,45). This, as will be shown in the analysis of Psalm 44, can be interpreted as God's actions against his people. When they found themselves in a situation of shame, the psalmists would pray that the enemies of the nation should be put to shame in a great reversal of their present circumstances (Ps. 129:5; 289).

God's honour is often the focus of the psalms. In the psalms of praise the psalmists give honour to God for who He is and for what He has done (cf. Pss. 8; 9; 18; 29; 30; 34; 100; $118 ; 145 ; 148 ; 150)$. In addition to this the psalmists would often claim that it is in God's best interests to deliver them in times of need, asserting that the manifestation of God's honour in the world is indeed at stake (cf. Pss. 9:14; 22:21-22; 35:17-19,27-28;

6 For an overview of the different Hebrew terms denoting shame, cf. Tucker 2007:467-468; cf. also Olyan 1996:203-204. 
$71: 14,16,18,23-24 ; 79: 13 ; 106: 47){ }^{7}$ The death of the psalmist would decrease the praise of God and the acknowledgment of his honour in the world (cf. Pss. 30:9; 88:10-12; 115:17). The psalmists insisted that God's honour would be advanced when a person, who already gives God honour through his praises, is restored to a position of honour and life. This idea is enhanced when one takes into account that the person thus restored, would act as an honourable client who returns thanks and praise to his divine patron (289-290).

God's honour is also at stake when the honour or safety of the righteous is threatened, because the unrighteous would use the downfall of the upright as proof of God's weakness or non-existence (cf. Ps. 42:10). This is also true when it comes to the destiny of the nation of Israel. God's honour is revealed to the nations when Israel is delivered in times of trouble (cf. Pss. 83:16-18; 98:1-3; 102:13,15; 115:1-2). Conversely, when Israel is humiliated before other nations, God's honour and strength in relation to the gods of these nations are called into question. The psalmists therefore appealed to God to come to Israel's rescue and restore their honour; thus ensuring that his honour and reputation would also be vindicated (cf. Pss. 74:10,18,22; 79:9-10,12; 115:1-2). When the other nations challenge God's honour by going after his covenant partner, God's hand is forced - He must accept the challenge and act favourably towards his people in order to maintain and restore his own honour (290-291).

This overview demonstrates that a triangular relationship exists between God, the psalmist and the enemy regarding honour and shame. Shame language is often utilized in reference to the psalmist-enemy relationship; shame also occurs frequently in the Godenemy relationship, often with God's honour at stake. In the God-psalmist relationship the poets would regularly appeal to God to remove their shame and restore them to a position of honour, or they would pray that shame would be cast upon the enemy, or that the shame ascribed to Yahweh, must be removed (cf. also Tucker 2007:468-469).

Tucker (2007:469-470) has pointed out that although studies on honour and shame in the Hebrew Bible have mostly followed cultural anthropologists in their claim that honour and shame function as a gender-based system, when studying the Book of Psalms the language of honour and shame seems to be lacking the sexual imagery habitually present in narrative texts.

How then should we proceed to analyse the Psalter as regards honour and shame? Two possibilities are feasible: Olyan (1996:201-218) has argued that honour and shame are situated within the context of covenantal relations, while Hobbs (1997:501-503) has opted for the patron-client relationship (cf. also Tucker 2007:465-480). To my mind, both these two approaches are valid methods of understanding honour and shame within the Book of Psalms. For the purpose of this article, my focus will be on honour and shame within the context of covenantal relations, as covenant is an obvious theme in Psalm 44 (cf. vv 2-4, 18).

\section{Analysis of Psalm 44}

\section{Stanza 1 (verses 2-9)}

start here Verses 2-4 call to mind the exodus and Israel's entrance into the Promised Land (cf. Ex 15:7; Jos 3:10; Pss. 78:54-55; 80:9-10; 105:44; 111:6; 135:10-12). God first gave the promise of the land when He established his covenant with Abraham. The narrative of the Pentateuch provides a distinct picture that the land was Israel's destiny, because God

7 Cf. Glatt-Gilad (2002:63-74) who investigated the theme of Yahweh acting for the sake of his reputation in a number of biblical texts. 
ordained it to be so as part of the covenant relationship. Psalm 44 reinforces this idea. God defeated the other nations on behalf of his people. Israel did not take possession of the Promised Land through the strength of their military prowess, but by the power of God's hand, because He loved them (cf. Dt. 4:37-38, 7:7-8, 9:4-6). Verse 3 contrasts God's actions on behalf of his people with his deeds against their enemies. He drove the nations out, but planted his people, He crushed the enemies, but Israel flourished.

Verse 4 presents an explanation of how the victory was accomplished. It did not happen through Israel's military strength, but through God's might and power. His presence enabled them to be victorious over their enemies. These verses also refer to the tradition of the holy war. God Himself is partaking in the war, and Israel's enemies become his enemies. God is portrayed as a warrior, fighting on behalf of his people.

God's actions on behalf of his people resulted in their occupying a position of honour amongst the nations. Everything is as it should be. Their covenant partner has proven Himself to be faithful and they are therefore not ashamed before their enemies. It is therefore clear that Israel's honour as a nation cannot be separated from their covenant relationship with God. He placed them in a position of honour by his faithfulness towards his covenant promises.

Verses 5-9 celebrate the victories that God has accomplished in the past. He is Israel's king and God. The poet thus accentuates the personal relationship between God and his people. They belong to Him, they are his possession, they live in covenant relationship with Him, and therefore they could expect that He would be there for them in any situation of need. Verse 6 is parallel to verse 3. God is celebrated in both verses as the One who gives victory, with verse 3 referring to the past, and verse 6 to the expectation of the present. Verses 7 and 8 correspond with verse 4 . The powerlessness of human weaponry is again contrasted with God's power and might to deliver his people.

God's deeds of salvation not only resulted in honour for his people, but also in shame for the nations. The poet is explicit: It is God who has shamed those who hate Israel (verse 8). His shaming of the enemies will, conversely, ensue in honour, not only for Israel, but also for God. He has shown Himself to be more powerful than the enemies; they were not able to stand before Him, but were brought to shame. The poet underlines the fact that God's honour and the honour of his people are intertwined. Israel occupies a position of honour due to God's victory and his shaming of the enemies; this same victory also attests to the honour of God. Israel's honour and God's honour, and the shame of the enemies result from God acting as He is supposed to as faithful covenant partner. When God stays true to his covenant, Israel's social status and place of honour amongst the nations are ensured.

The stanza concludes with a doxology (verse 9) affirming Israel's praise of God for what He has done for them. They will indeed boast in Him, not in their own abilities, because He won the victory.

This first stanza presents to us the ideal situation. Israel, with Yahweh as covenant partner would expect to enjoy a position of honour amongst the nations. They would expect that their trust in God and their faith in Him would result in their enjoying honour. The enemies, those who do not fear Yahweh, should be shamed, as is the case in this stanza. When the enemies are shamed and when Israel experiences honour, God's honour is also revealed. Israel's honour is indeed a reflection of God's honour.

Stanza 2 (verses 10-17) 
In shrill contrast to the first stanza, the second stanza abounds in language of shame. The tragedy expounded in this stanza is not only that Israel now experiences shame, or even that the enemies have shamed and disgraced God's people, but that God is responsible for the shaming of his covenant partner. God has rejected his people. ${ }^{8}$ This theme occurs often in the psalms (cf. Pss. 22:2; 39:9; 43:2; 69:10-13; 71:11; 74:1; 79:4; 89:39-46; 108:12; cf. also Jdg. 6:13; Is. $2: 6 ; 49: 14$ ). The use of the second person singular verbal forms in verses 1015 emphasizes God's culpability. This contrasts sharply with the uses of the second person singular verbal forms in the first stanza. There God ('You') acted on behalf of his people and against the enemies, here God acts against his people. Instead of saving his people from the enemy, God has now become the major foe who empowers the enemies and disgraces his people (cf. Rom-Shiloni 2008:687). The alliteration pattern of verses 11-15 (all beginning with the letter $ת$ as initial letter) accentuates God's actions against his people.

God's rejection is experienced in different ways: He no longer goes out with the armies of Israel; consequently they suffer defeat in war (verses 10-11). This highlights the important role of honour and shame in international relations. Simkins (1994:51) has pointed out that although in most Mediterranean cultures the quest for honour and the avoidance of shame occurs within a familial context, in the Bible the language of honour and shame is also applied to international relations. The honour or shame of God's people depends on their status as a nation in relation to their neighbours. The destruction of Judah is repeatedly described as a source of shame (Jer. 3:3,25; 9:19; Lam. 5:1; Neh. 1:3; 2:17). Furthermore, God's absence is also deemed to be shameful to the people (Mic. 3:7; Jer. 48:13), for this demonstrates their vulnerability or helplessness before other nations. Moreover, defeat in war also reflected badly on one's god, indicating his powerlessness before the gods of the enemies, which resulted not only in shame for the nation, but also shame for one's god. In the first stanza God's honour was intertwined with Israel's honour, now Israel's shame also created shame for their God. What makes it incomprehensible is of course God's responsibility in the matter. This makes a mockery of Israel's claim to be Yahweh's covenant partner and to enjoy the advantages of allegiance to Him. If Yahweh was their God (as they claimed) and if the people had honoured Him through obedience to his will, then it was incumbent upon Yahweh to bless and protect them (cf. Simkins 1994:51).

Instead He rejects them, shames them, and gives them up to be devoured like sheep, which is a picture of doom (cf. Jr. 12:3; Zech. 11:4, 7). They became like sheep that perished in the open fields, whose remains were consumed by scavenging animals and birds (cf. Pss. 74:14, 79:2; Jr. 7:33, 16:4, 19:7, cf. Goldingay 2007:43). He scatters them among the nations (verse 12), selling them for a pittance, without gaining anything from the sale (verse 13). It is as if He couldn't get rid of them quickly enough, not holding out for a fair price (cf. Eaton 2003:184); apparently they were without value in God's eyes. Amos 2:6 speaks of the ungodly selling the righteous for silver and for a pair of sandals. At least they got something of worth from their unrighteous practices. Yet, God gains nothing from selling his people; apparently He doesn't care enough. ${ }^{9}$

He makes them a reproach to their neighbours, the scorn and an object of ridicule to those around them (verse 14), He makes them a byword amongst the nations (verse 15),

8 Cf. Leung Lai (2007:426) who refers to this portrayal of God as abusive. Rom-Shiloni (2008:685) rightly points out that Psalm 44 is one of very few communal laments where the responsibility for the destruction of God's people is put on God, while the role of human enemies is secondary.

9 Goldingay's (2007:43) metaphor is extremely descriptive: "They have been put on eBay for a few cents, with no reserve). 
which indicates what happens when you trust in a god who cannot deliver, or if you think that God is with you when He is not (Goldingay 2007:44). People who see this shake their heads, indicating that Israel has become the laughing stock of the nations. The expression also suggests the horror of those seeing Israel's fate (cf. Jr. 18:16, cf. Goldingay 2007:44). Due to God's rejection, the psalmist, along with his people, is covered with disgrace and shame (verse 16) as the enemies, bent on revenge, taunt, revile and reproach them (verse 17). The fact that God has now turned against his people has resulted in the enemies' triumph. Instead of the enemies' being put to shame, as was the case in the first stanza, God's people are now put to shame.

As Yahweh's covenant partner, Israel, due to their obedience to the covenant, should have occupied a position of honour, as was the case in the first stanza. They displayed the proper attitudes and behaviour towards God. Yet, this God has shamed them. A question that arises immediately is whether God's rejection of his people indicates a failure of relationship (cf. Cottrill 2008:69-74). Cottrill (2008:70) has pointed out that the failure of trusted relationships results in public shame, which in turn translates into feelings of internal shame. Israel certainly would have experienced emotions of unworthiness and inadequacy due to their rejection by God.

Shame is perceived here to be relational, however not as the result of failure on the part of Israel, but failure on the part of their covenant partner to live up to the obligations of the covenant. God is the one who betrayed his people; He is disloyal; He is unfaithful to the trust they have placed in Him. The rhetoric of trust often found in psalms of lament (cf. Cottrill 2008:108-114) has changed into rhetoric of betrayal. The people are shamed, even though they were not guilty of betrayal or deception. By nature, the covenant relationship affirmed who Israel was: they belonged to Yahweh; their sense of self was defined by their covenant relationship. Yahweh's actions now threatened their sense of belonging to this relationship that gave significance and substance to their existence. How do they react to this rejection? With a discourse on their innocence and an appeal to the same God who rejected them to intervene and save them (cf. next strophe). The purpose of this rhetoric is that they should once again be restored to a position of honour.

It is incomprehensible to the people that God, their covenant God, acts contrarily to what He has done in the past. Instead of delivering them, He is the one who delivers them into the hands of the enemy. He is responsible for everything that has happened to them; $\mathrm{He}$ carries the blame for their shame, for their pain; He is liable for their suffering. The people accuse God of being unjust and unfair. This accusation should be understood as the unburdening of a people who feel that God has forsaken and betrayed them, people who feel that everything they believed in and trusted in has been shattered, that everything around them has turned into darkness. These are the words of a people who experience God as their enemy.

\section{Stanza 3 (verses 18-23)}

The idea that God is responsible for Israel being disgraced is reinforced in stanza 3 with the "not guilty" plea of the poet. The "not guilty" plea occurs elsewhere in the psalms as well (cf. Pss. 7:4-6; 17:3-4; 26:4-6; 59:4-5). The psalmist asserts that God's people have not been unfaithful to the covenant, nor have they forgotten Him, nor gone off track by following other gods. In verse 18 the psalmist claims that they have not been unfaithful in their hearts or their steps. This indicates their faithfulness both in their inner person and their outward activity (Goldingay 2007:45). 
This claim makes God's conduct all the more incomprehensible. If they had sinned and served other gods (which they have done on numerous occasions) God's behaviour would have been justified. Generally in psalms of communal lament that is the case. Yahweh is typically presumed to be responsible for the suffering of the community because of their disobedience (cf. Pss. 74:1; 79:5; 80:5; 89:39), but here they are innocent of wrongdoing; therefore they blame God for their shame and disgrace. This "not guilty" plea stands in sharp contrast to the usual blessing-curse scheme of Deuteronomistic covenant theology. ${ }^{10}$

According to Deuteronomy 28 Israel could expect blessings to follow their faithfulness to the covenant, and curses to follow their unfaithfulness. As Yahweh's covenant partner, Israel should have occupied a place of honour, because they are innocent of any wrongdoing. Their behaviour was in line with Deuteronomistic theology, they were obedient, and therefore they should have been blessed and honoured. Yet the opposite happens: Despite their faithfulness, they were shamed. They did their part, God did not. He betrayed his people, He is disloyal and unfaithful. Their devotion to God is repaid by their becoming a haunt for jackals, a place of complete desolation no longer fit for human abode, indicating total ruin (Goldingay 2007:46). They are are shamed, even though they were innocent of betrayal or deception.

How does Israel react to this rejection? What is their response to this capricious God, this God who shames them? They plead their innocence; they appeal to this same fickle God who rejected them and who is responsible for their shame to intervene and save them and restore them. The purpose of this rhetoric is that they should once again be restored to a position of honour. They pray for a reversal in their fortunes, they plead for their vindication, that their innocence is recognized by God and they be returned to a position of honour, as is their due because of their innocence.

\section{Stanza 4 (verses 24-27)}

Israel does not accept God's actions against them stoically. After blaming Him for their loss of honour in stanza 2, and protesting their innocence in stanza 3, here in stanza 4 they

10 In the words of Hossfeld \& Zenger (1993:277): "Mit dieser "Unschuldungsbeteuerung" bricht der Psalm das Psalm das traditionelle Segen-Fluch-Schema der der Bundestheologie auf und stösst so zu einer vertrieften Sicht der Bundesgemeinschaft zwischen Israel und seinem Gott vor: Das Festhalten am Gottesbund bewahrt nicht vor Katastrophen und vor Leiden, im gegenteil!" Cf. also Rom-Shiloni 2008:690-693 who argues that Psalm 44 stand explicitly against Deuteronomic conventions, and also against prophetic texts like Jeremiah $2: 32 ; 18: 13-17$ that put the blame for Israel's suffering on their forgetting God's covenant. Jeremiah uses Deuteronomic themes in his prophecies of judgment to lay the blame for the current distress on the disobedient people (Jer $3: 21 ; 13: 25 ; 23: 27)$. In two series of rhetorical questions, the prophet expresses Israel's inexplicable behaviour. In Jeremiah 2:32 he asks: "Can a maiden forget her jewels; a bride her adornments? Yet my people have forgotten Me". Subsequently, in Jeremiah 18:13-17, the prophet describes the people's conduct as unheard of. The accusation in Jeremiah is that the people have forgotten God. In Psalm 44:18 however, the poet vehemently negates this accusation. The image of transgression as straying off the road implying the worship of other gods (Jer. 18:15) is rejected by the psalmist in verse 19. Both texts claim the active role that God will play in the punishment to come. A major difference is of course that the poet pleads innocent in Psalm 44. This means that Psalm 44 "stands explicitly against these and other similar Deuteronomic and prophetic conventions, opposing the more usual explanation that places all blame for the current situation on the people's violation of the covenant. In refuting these conventions, Psalm 44 joins proclamations heard in nonorthodox sources, including other communal laments (Pss. 42:10; 74:19; 77:10; Lam. 5:20) and in prose prayer (1 Sam. 1:11). Like Psalm 44, these texts give precedence to the feeling of desertion and neglect. They call on God not to forget obedient servants/people and not to withdraw from the long-standing covenant (Pss. 74:20; 89:50); also the communal lament in Jer. 14:19-22" (Rom-Shiloni 2008:693). 
accuse Him of sleeping. This puts God in the same category as gods like Baal, whose prophets were mocked by Elijah at Mount Carmel, when he accused Baal of sleeping (cf. 1 Ki. 18:27). Yet God is the God of whom Psalm 121:4 declares that He never sleeps! Israel's testimony about God was that He never sleeps nor slumbers (Ps. 121:4). Here God is placed on the witness stand and accused of being in fact like the other gods, who sometimes sleep. The poet uses the rhetoric of accusation to plead their case further for a reversal of fortune and a restoration of honour.

The poet is confronted with the horrifying experience of God's silence. The question, "why do you sleep", is not a quest for information, but a rhetorical question accusing God that he is acting differently from what He is supposed to do. It is a desperate cry born from deep despair and pain. God has abandoned them, his neglect has resulted in their disgrace and shame, they are bowed down in the dust, humiliated, yet they still call upon God to intervene. Although $\mathrm{He}$ is against them, and responsible for their shame and humiliation, $\mathrm{He}$ is the only one who can turn the circumstances around, give new life and restore their honour.

In the last verse the psalmist appeals to God's love (חֶֶ) as motivation for his deeds of deliverance (cf. also Pss. 6:5; 25:7; 107:20; 136; 2 Chr. 20:21-22). Here it is not only the attribute of love that is being referred to, but acts of love on behalf of Israel. The point is that Israel's shame reflects shamefully on Yahweh. It is therefore also in God's best interest to reverse Israel's fortunes. The poet therefore petitions God's love and faithfulness to his covenant in the hope that it will result in acts of redemption. God's love is indeed not static, but results in action of deliverance. Because He has demonstrated his love in the past, Israel trusts that, although it seems He had forgotten them, He will rise up once more to fight for them. Against God, they still cling to God. Although the covenant God is acting contrarily to what they expected of Him, his covenant love still is their only hope for redemption and restoration of their honour.

By using the rhetoric of accusation, Israel is in fact shaming God into action. The God of Israel, the God who supposedly never sleeps, this God is asleep. This accusation places shame on Yahweh, for He is not supposed to be sleeping. Israel thus uses shame language to awaken God to action on their behalf.

\section{Summary and Conclusions}

In this article I have addressed the issues of honour and shame in Psalm 44 - fundamental social values of the ancient Mediterranean world. Honour was the purpose, passion and expectation of anyone desiring to be successful in life. Being shamed was a social disaster. Honour and shame took a central place in relationships between humans and similarly played a crucial role in the relationship between God and human. As Israel's covenant partner Yahweh's honour was intertwined with the honour of his people, and their shame also reflected negatively on Him.

What is the role of honour and shame in the triangular relationship between God, the psalmist and the enemy in Psalm 44?

The first stanza reflects very positively on Israel's honour and the other nations' shame. With joyful exuberance Israel remembers and celebrates God's glorious deeds on their behalf. This stanza presents the ideal situation. Israel, living in covenant with Yahweh, would expect to enjoy a position of honour amongst the nations. Their trust and faith in Him should result in honour. God's actions on behalf of his covenant partner would not 
only result in their honour, but would also reveal God's own honour. As victorious God, He is honoured among the nations. Here we see that God's honour and the honour of his covenant partner are intertwined. When God acts as He is supposed to, the result is clear: Honour for God, honour for Israel, but shame for the nations. Yahweh played an active role in bestowing honour on his people; He also played an active role in the shaming of the enemies.

The lament of stanza 2 abounds in language of shame. The tragedy spelled out in this stanza is not only that Israel now experiences shame, or even that the enemies have shamed and disgraced God's people, but that God is responsible for the shaming of his covenant partner.

God has rejected and humbled them; they are disgraced and shamed. God's rejection is experienced in different ways; the end result is that Israel is covered with disgrace and shame.

The honour or shame of God's people depends on their status as a nation in relation to their neighbours. Defeat in war resulted not only in shame for the defeated nation, but also reflected badly on one's god, indicating that he is powerless before the gods of the enemy nations. This resulted not only in shame for the nation, but also in shame for one's god. In the first stanza God's honour was intertwined with Israel's honour, now Israel's shame also created shame for their God. What makes it incomprehensible is of course God's responsibility in the matter. God is the one who has betrayed his people; He is disloyal and unfaithful to the trust they have placed in Him. The people are shamed, even though they were not guilty of betrayal or deception.

How do they react to this rejection? What is their response to this unpredictable God, this God who shames them? Israel responds with a discourse in stanza 3 on their innocence and an appeal to the same God who rejected them to intervene and save them. The purpose of this rhetoric is that they should once again be restored to a position of honour. The claim of innocence is an expression of their belief that they don't deserve their position of shame, and that they should be restored to a position of honour.

In stanza 4 the people petition God to act again on their behalf and thus change their shame into honour. God is accused of being like the other gods, who sometimes sleep. The poet uses the rhetoric of accusation to plead their case further for a reversal of fortune and a restoration of honour. They are in fact shaming God, because He is not supposed to be sleeping. God's rejection has resulted in their disgrace and shame, they are bowed down in the dust, humiliated, yet they still call upon God to intervene. Although He is against them, and responsible for their shame and humiliation, $\mathrm{He}$ is the only one who can turn the circumstances around, give new life and restore their honour. Although the covenant God is acting contrarily to what they expected of Him, his covenant love still is their only hope for redemption and restoration of their honour.

A few concluding points concerning honour and shame in Psalm 44:

- Israel enjoys honour as a result of God's faithfulness to his covenant.

- The honour of the nation is intertwined with God's honour.

- God is responsible for shaming the enemies.

- God is responsible for shaming his covenant partner.

- Israel's shame reflects negatively on Yahweh.

- Israel employs rhetoric of betrayal and accusation, as well as a plea of innocence to reverse their position. 
- Israel recognizes that although God betrays and shames them, He is still the only one who can restore their honour.

- Israel uses the rhetoric of accusation in order to shame Yahweh, thus forcing Him into action on their behalf.

\section{BIBLIOGRAPHY}

Bartusch, MW 2009. From honor challenge to false prophecy: Rereading Jeremiah's story of prophetic conflict in light of social-science models. Currents in Theology and Mission 36(6):455-463.

Bechtel, LM 1991. Shame as a sanction of social control in biblical Israel: Judicial, political, and social shaming. JSOT 49:47-76.

Bergant, D 1994. "My beloved is mine and I am his" (Song 2:16): The Song of Songs and honor and shame, in Matthews, VH \& Benjamin, DC (eds.), "Honor and shame in the world of the Bible”, 23-40. Atlanta: Scholars Press. Semeia 68.

Botha, PJ 1998a. The 'Enthronement Psalms': A claim to the world-wide honour of Yahweh. OTE 11 (1):24-39.

Botha, PJ 1998b. To honour Yahweh in the face of adversity: A socio-critical analysis of Psalm 131. Skrif en Kerk 19(3):525-533.

Botha, PJ 1999. Shame and the social setting of Psalm 119. OTE 12(3):389-400.

Botha, PL 2001. Honour and shame as keys to the interpretation of Malachi. OTE 14(3):392-403.

Botha, PJ 2002. 'The honour of the righteous will be restored': Psalm 75 in its social context. OTE 15(2):320-334.

Brayford, SA 1999. "To Shame or Not to Shame: Sexuality in the Mediterranean Diaspora.” Semeia 87:163-176.

Cottrill, AC 2008. "Language, power, and identity in the lament psalms of the individual" New York: T\&T Clark. Library of Hebrew Bible/Old Testament Studies 493.

Crook, Z 2009. Honor, shame, and social status revisited. JBL 128(3):591-611.

DeSilva, DA 2008. Honor and shame, in Longman, T \& Enns, P (eds.), Dictionary of the Old Testament wisdom, poetry \& writings, 287-300. Downers Grove: IVP Academic.

Eaton, J 2003. The Psalms: A historical and spiritual commentary with an introduction and new translation. London: T\&T Clark.

Glatt-Gilad, DA 2002. Yahweh's honor at stake: A divine conundrum. JSOT 98:63-74.

Goldingay, J 2007. Psalms Volume 2: Psalms 42-89. Grand Rapids: Baker. (Baker Commentary on the Old Testament Wisdom and Psalms.)

Hobbs, TR 1997. Reflections on honor, shame, and covenantal relations. JBL 116(3):501-503.

Hossfeld, F-L \& Zenger, E 1993. “Die Psalmen I: Psalm 1-50. ” Würzburg: Echter. NEB.

Leung Lai, BM 2007. Psalm 44 and the function of lament and protest.

OTE 20(2):418-431). 
Matthews, VH \& Benjamin, DC (eds.) 1994. "Honor and shame in the world of the Bible". Atlanta: Scholars Press. Semeia 68.

Matthews, VH \& Benjamin, DC 1994. Introduction: Social sciences and Biblical studies, in Matthews, VH \& Benjamin, DC (eds.), "Honor and shame in the world of the Bible”, 7-21. Atlanta: Scholars Press. Semeia 68.

Matthews, VH 1998. Honor and shame in gender-related legal situations, in Matthews, VH, Levinson, BM \& Frymer-Kensky, T (eds.), "Gender and law in the Hebrew Bible and the Ancient Near East", 97-112. Sheffield: Sheffield Academic Press. JSOT supplement series 262 .

Odell, MS 1992. The inversion of shame and forgiveness in Ezekiel 16:59-63. JSOT 56: 101-112.

Olyan, SM 1996. Honor, shame, and covenant relations in ancient Israel and its environment. JBL 115(2):201-218.

Robbins, VK 1996. Exploring the texture of texts: A guide to socio-rhetorical interpretation. Harrisburg: Trinity.

Rom-Shiloni, D 2008. Psalm 44: The powers of protest. CBQ 70:683-698.

Simkins, RA 1994. "Return to Yahweh": Honor and shame in Joel, in Matthews, VH \& Benjamin, DC (eds.), "Honor and shame in the world of the Bible", 41-54. Atlanta: Scholars Press. Semeia 68.

Stansell, G 1994. Honor and shame in the David narratives, in Matthews, VH \& Benjamin, DC (eds.), "Honor and shame in the world of the Bible," 55-79. Atlanta: Scholars Press. Semeia 68.

Stone, K 1995. Gender and homosexuality in Judges 19: Subject - honor, object - shame? JSOT 67:87-107.

Tucker, WD 2007. Is shame a matter of patronage in the Communal Laments? JSOT 31(4):465-480. 